\title{
Razvoj, rast in zorenje možganov
}

\author{
Pediatrična klinika, Klinični oddelek za otroško, mladostniško in razvojno nevrologijo
}

Povzetek: Razvoj, rast in zorenje možganov danes spremljamo z longitudinalnimi študijami zdravih otrok. Zelo dragoceno je longitudinalno psihološko sledenje razvoja ter ob tem slikovna diagnostika z magnetno resonančnim slikanjem (MRI), ki jo lahko nadgradimo z meritvami kot sta morfometrija in volumetrija. V prispevku predstavimo nekaj ključnih spoznanj o razvoju možganov, ki ponudijo uvid v nekatere vidike otrokovega razvoja. Osredotočimo se na pomembna razvojna obdobja, vključno s prenatalnim obdobjem. Opišemo procese, ki delujejo na zgradbo in delovanje možganov. Predstavimo spremembe v beli možganovini, področno značilne razvojne krivulje v kortikalni sivi možganovini ter specifična področja subkortikalnih struktur. Opišemo značilnosti in posebnosti delovanja možganov med zorenjem. S prispevkom osvetlimo nekatere ključne nevroanatomske procese, ki vplivajo na vedenje otrok.

Ključne besede: možgani, razvoj, otroci, mladostniki, občutljivo obdobje, magnetnoresonančno slikanje (MRI).

\section{Brain development, growth, and maturation}

University Children's Hospital, Department of Child, Adolescent and Developmental Neurology, Slovenia

\begin{abstract}
Longitudinal studies of healthy children enable us to explore and follow development, growth, and maturation of brain. Of high value are longitudinal psychological studies combined with magnetic resonance imaging (MRI) which can be advanced to brain morphometric and volumetric studies. In the article we present key findings related to brain development and provide the insight into some aspects of child development. We focus on developmental key periods including the prenatal period. We describe the processes which influence the brain structure. Changes in white matter, regionally specific trajectories of grey matter and some subcortical structures are presented. We describe characteristics of brain functioning during development and maturation. The article gives the insight into some pivotal neuroanatomical processes which influence child behaviour.
\end{abstract}

Key words: brain, development, children, adolescents, critical period, magnetic resonance imaging (MRI)

\footnotetext{
${ }^{*}$ Naslov/Address: Tina Bregant, dr. med., Klinični oddelek za otroško, mladostniško in razvojno nevrologijo, Pediatrična klinika, Univerzitetni klinični center Ljubljana, Bohoričeva 20, 1000 Ljubljana, e-mail: tina.bregant.drmed@gmail.com

Članek je licenciran pod pogoji Creative Commons Attribution 4.0 licence. / The article is licensed under a Creative Commons Attribution 4.0 International License.
} 
Povprečni možgani odraslega človeka tehtajo 1400 gramov, kar je približno 2 odstotka telesne teže, in porabijo 20 odstotkov vsega kisika, ki je na voljo telesu. Ob rojstvu donošenega, zdravega novorojenčka možgani tehtajo 300 g, kar predstavlja približno $10 \%$ telesne teže. Tekom odraščanja lahko opazujemo rast in razvoj, pa tudi zorenje možganov. Ti procesi omogočajo pridobivanje in usvajanje veščin in znanj, ki so kasneje značilne za odrasle.

Odrasli in otroški možgani se razlikujejo tako po teži, videzu, anatomskih in biokemičnih značilnostih kot tudi po procesih, ki se v njih odvijajo. Od $300 \mathrm{~g}$ ob rojstvu do 1400 g v odraslosti, od praktično na površini gladkih do primerno nagubanih, od nemieliziranih in prostorninsko manjših do polno mieliziranih možganov preteče 20 do 30 let. Kaj se dogaja v možganih med procesom zorenja lahko opazujemo z anatomskega vidika, kar nam omogoča magnetno resonančno slikanje (MRI), s katerim si lahko prikažemo zorenje posameznikovih možganov z zaporednim, longitudinalnim sledenjem zdravih otrok. Iz opazovanja otrok in njihovega vedenja sklepamo na njihovo delovanje (velja tudi obratno), kar lahko dodatno povežemo in podkrepimo $\mathrm{z}$ izsledki funkcionalnega slikanja z magnetno resonančnim tomografom (fMRI). Razumevanje razvoja možganov so nam poleg slikovnih tehnik dodatno omogočile tudi genetske raziskave in nevropatološke študije, ki se navezujejo na izsledke kirurškega zdravljenja epilepsij. V članku smo se osredotočili zlasti na razvojna obdobja možganov, ki jih zlahka prepoznamo predvsem s sodobnimi slikovnimi metodami.

\section{Embriologija razvoja možganov}

V blastocisti se 5. do 7. dan razvoja pričnejo oblikovati klični listi. Okrog 14. dne po oploditvi se celice zarodka diferencirajo $\mathrm{v}$ zarodne klične plasti: endoderm, mezoderm in ektoderm. Z nastankom embrionalnih plasti je omogočena organogeneza. Možgani, živci, povrhnjica kože, lasje, nohti, sredici nadledvičnice in povrhnji del prebavil, pa tudi očesna leča in mrežnica ter mlečna žleza, se razvijejo iz zunanjega kliničnega lista (ektoderma) . Ektoderm sprva leži na površju zarodka, nato pa se v zgornjem delu odebeli, uviha in postane podoben cevi. Tako dobimo zunanjo plast in znotraj telesa neke vrste »cev«, ki se oblikuje in napihne v mehurčke, ki kasneje postanejo veliki in mali možgani, podaljšana hrbtenjača in hrbtenjača. Temu pravimo nevrulacija. Zaključi se do 4. tedna gestacije in predstavlja ključno obdobje za razvoj simetričnih, celostnih možganov. Napake iz tega obdobja so napake zapiranja živčne cevi: npr. anencefalija, spina bifida, meningokela (Haslam, 2000).

Med 4. in 6. tednom zaznamo bitje srca in tudi že prvo aktivnost, ki izhaja iz živčnega sistema. Od 6 . tedna dalje, ki ga imenujemo nevrogeneza, se posamične celice pričnejo razlikovati. Znotraj možganov so votline, ki se bodo izoblikovale $\mathrm{v}$ možganske prekate. $\mathrm{V}$ njihovi bližini se oblikujejo proliferativne cone, kjer nastajajo novi nevroni (Clowry, Molnar in Rakic, 2010). Nastajajo tudi podporne celice, ki omogočijo kasnejšo migracijo nevronom. To obdobje imenujemo proliferacija in določa, kolikšno bo grobo, končno število nevronov in podpornih celic v 20. tednu. Napake iz tega obdobja so holoprozencefalija, kiklopija, kolpocefalija z mikrocefalijo ter megalencefalija. Med 12. in 20. tednom se nevroni množijo in migrirajo vzdolž celic glije. Nevroni se selijo od znotraj navzven, od zadaj naprej, tiste celice, ki bodo najbolj zunaj v možganih, se tja naselijo najkasneje. To določa grobi videz možganov. Migracija iz ventrikularnih območij sicer v manjši meri poteka vse do 4. meseca po rojstvu. Napake iz obdobja migracije nevronov so agirija, pahigirija, lisencefalija in shizencefalija. Ko je migracija $v$ grobem končana, pride do hitrega, znatnega propada celic $\mathrm{z}$ apoptozo. Število nevronov se od 24. tedna gestacije do 4 . tedna po rojstvu zmanjša na polovico. Tako lahko rečemo, da novorojenčki izgubijo že polovico svojih nevronov še preden se rodijo. Ta proces imenujemo redčenje, pomeni pa propad nepotrebnih nevronov, ki ne dobivajo dovolj signalov.

Od 17. do 30. tedna, z vrhom v 24. tednu, prihaja do prehodne populacije celic tik pod možgansko skorjo (Kostovic in Rakic, 1990). Imenujemo jo podplošča in vpliva na kasnejšo kakovost povezav med celicami. Tega sloja po 30. tednu ne vidimo več dobro. Kljub temu prav podplošča pomembno prispeva $\mathrm{h}$ končnemu delovanje možganskih celic in na njihove medsebojne povezave. Podplošča je lahko okvarjena pri nedonošenčkih in vpliva na kasnejši razvojni izid (Miller in Ferriero, 2009).

Od 20. tedna dalje poteka organizacija nevronov, njihovo brstenje in intenzivno povezovanje. Prične se sinaptogeneza, tj. tvorba sinaps, ki traja vse življenje in od 24. tedna tudi mielinizacija; organizacija podpornih celic ter odlaganje mielina, ki se znatno pospeši po 36. tednu in omogoča hitre povezave med celicami. Mielinizacija poteka za različna področja različno; možgansko deblo mielinizira pri 29 tednih (Huppi in Inder, 2001), arkuatni fascikel pa šele med 20. in 30. letom (Yakovlev in Lecours, 1967). Velja, da proksimalno nitje mielinizira pred distalnim, senzorično pred motoričnim, projekcijsko pred asociacijskim (Volpe, 2008). Mielinizacija v grobem poteka v smeri od spodaj-navzgor in od zadaj-naprej. Zelo pomembni in raznoliki nevroanatomski procesi se odvijajo večinoma prenatalno, kar lahko razberemo iz slike 1.

$\mathrm{V}$ približno 15 . tednu gestacije se površina možganov prične gubati (Levine in Barnes, 1999). Z izjemo zatilnega režnja vidimo v 28. tednu oblikovane glavne sulkuse, kasneje se razvijejo sekundarni in terciarni sulkusi. $\mathrm{Ob}$ rojstvu je giracija praktično končana. Vzorec in kompleksnost gubanja pa se spreminja, najverjetneje glede na gostoto celic in zorenje subkortikalnih traktusov.

Dotakniti se moramo tudi principa Evo-Devo (angl. Evolution-Development), ki postavlja fenotipsko uresničitev genotipa $\mathrm{v}$ filogenetski okvir (Finlay in Darlington, 1995). Specializacijo možganske skorje lahko razumemo kot genetsko določeno, lahko pa nanjo pogledamo tudi z vidika Evo-Devo. Empirični dokazi 


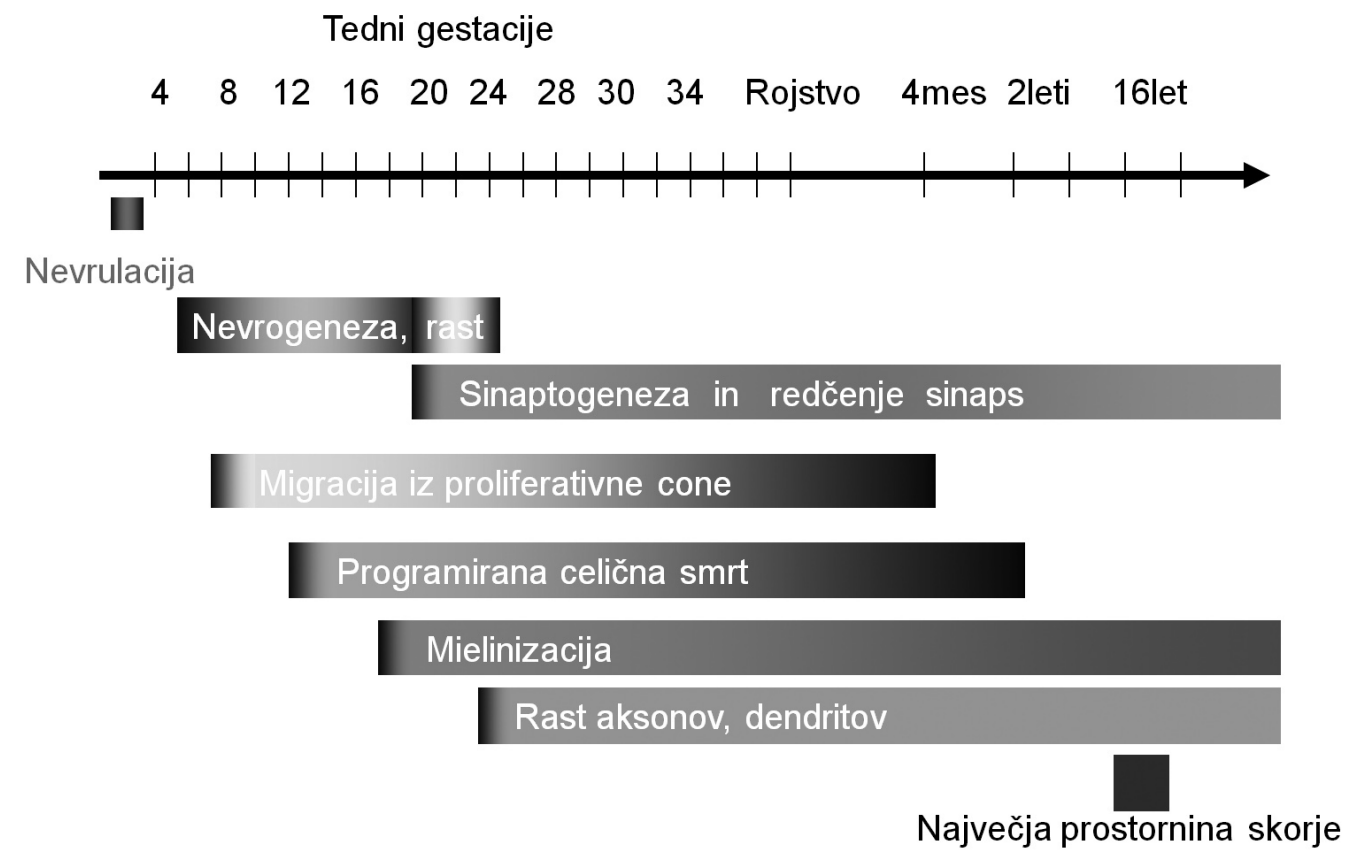

Slika 1 . Ključni procesi v razvoju možganov od oploditve do odrasle dobe.

govorijo namreč v prid dokončnemu razvoju možganov glede na okoljske vplive, ki so mu možganske strukture izpostavljene tekom razvoja.

Teorija protomape predpostavlja organizacijo predela okoli možganskih prekatov v skupine stolpičev, ki z migracijo v zunanje sloje oblikujejo enako urejeno možgansko skorjo (Ackerman, 1992; Rakic, 1988). Pri razvoju možganov tako poglavitno vlogo igrajo intrinzični dejavniki, ki so genetsko določeni. V prid genetskemu vplivu govorijo študije pri miših, kjer so z genetsko napako okvarili nastanek talamo-kortikalnega nitja, kar pa ni pomembno vplivalo na kasnejšo diferenciacijo skorje (Miyashita-Lin, Hevner, Montzka Wassarman, Martinez in Rubenstein, 1999).

Teorija protoskorje pa, ravno nasprotno, postavlja kot pomemben razvojni dejavnik vpliv proženja nevronov, torej ekstrinzične vplive. V prid slednjemu govori nujen vpliv talamičnega nitja na razvoj in organizacijo vidne skorje (Kennedy in Dehay, 1993). Ker spontano aktivnost nevronov zaznamo že $\mathrm{v}$ obdobju pred rojstvom, ne moremo izključiti njenega vpliva na razvoj možganskih struktur, kljub morebitnemu dejstvu, da je organizacija in diferenciacija skorje določena že pred tem (Shatz, 2002). $\mathrm{K}$ hipotezi protomape in protoskorje se bomo še vrnili, saj je njuno poznavanje ključno za razumevanje delovanja možganov in njihove kompleksnosti, ki, ne pozabimo, zahteva $\mathrm{v}$ razvoju posameznika dobri dve desetletji razvoja.

Rast in razvoj možganov je med nosečnostjo nadzorovan s strani posebnih molekul, hormonov in rastnih faktorjev, ki so v različnih obdobjih različni. Zato genetsko ozadje, hormonsko ravnovesje matere, spol ploda, prehrana v nosečnosti, dodatki kot folna kislina ali pa prisotnost alkohola in težkih kovin ter tudi bioloških agensov kot so okužbe, zlasti v najbolj občutljivem obdobju, pomembno vplivajo na razvoj možganov. Glede na embrio-fetalni razvoj lahko razlikujemo tako imenovana terminacijska obdobja, ki predstavljajo obdobje $\mathrm{v}$ razvoju organa, $\mathrm{v}$ našem primeru možganskih struktur, po katerem specifična malformacija ne more več nastati, ne glede na škodljiv dejavnik. Pravilo imenujemo »načelo po Warkanyju«.

\section{Razvoj možganov od otroštva do najstništva}

V nosečnosti je najpomembnejše nastajanje nevronov, $\mathrm{v}$ otroštvu pa sledi obdobje zorenja in rasti. Ob rojstvu možgani tehtajo le četrtino teže odraslih možganov. Pri dveh letih otroški možgani v povprečju dosežejo $80 \%$, pri petih letih v $90 \%$ in pri šestih letih $95 \%$ velikosti odraslih možganov (Bregant, 2010; Lenroot in Giedd, 2006), kar je razvidno iz slike 2.

Velikost možganov ne določa tudi njihove funkcije. Zdravi otroci iste starosti se lahko razlikujejo za $50 \%$ skupne prostornine možganov (Lenroot in Giedd, 2006). Pri otrocih opažamo tudi izrazito variabilnost v njihovem delovanju, kjer ob funkcionalnem magnetno resonančnem slikanju ugotavljamo izrazito variabilnost v sposobnosti reševanja naloge že znotraj posamičnega otroka, še bolj pa znotraj skupine enako starih otrok. S starostjo oziroma verjetneje $\mathrm{z}$ zorenjem struktur, vpletenih $\mathrm{V}$ reševanje naloge, pa se ta variabilnost zmanjšuje (Cedric idr., 2011). Pri morfometričnih študijah se je izkazalo, da ima dednost velik vpliv na volumen celotnih možganov $(0,77-0,88)$, volumen korpus kalozuma $(0,85)$ in majhen vpliv na volumen malih možganov $(0,49)$ (Giedd, 2008). Zanimivo 


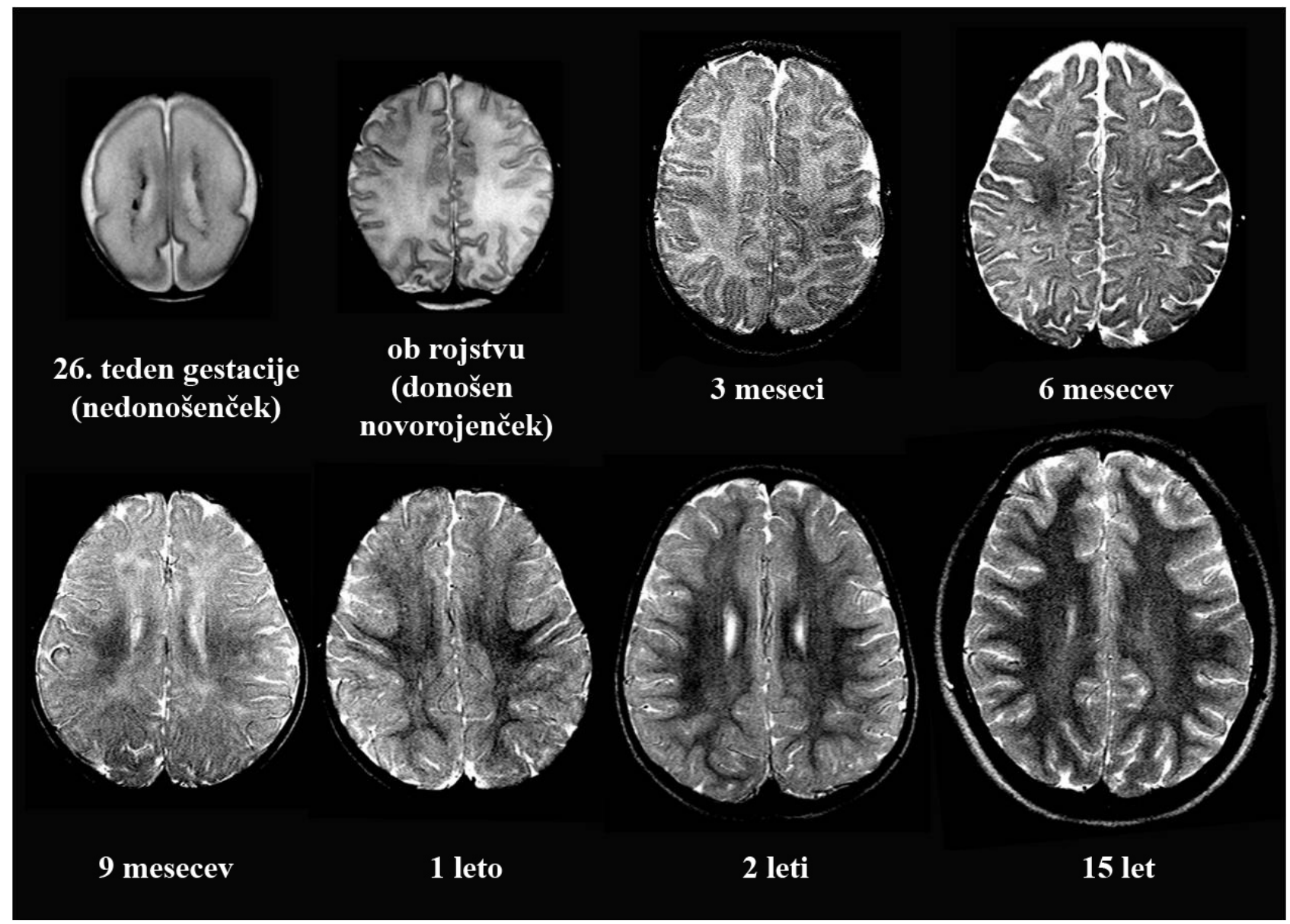

Slika 2. Razvoj možganov od 26. tedna gestacije do obdobja najstništva kot ga vidimo na slikanju z MRI. Vir: Bregant, T. (2010). Razvoj možganov [Brain development]. Proteus, 73(4), 168-174.

je, da le en genetski faktor vpliva na variabilnost kortikalne debeline do 60 \% (Schmitt, Wallace in Rosenthal, 2007), kar pritrjuje Rakićevi hipotezi neokortikalne ekspanzije (Rakic, 1995) in razlagi velikosti možganov pri različnih vrstah na račun mutacij genov zadolženih za zgolj nekatere, specifične funkcije (Finlay in Darlington, 1995).

Po rojstvu nevroni predvsem zorijo in se pričnejo biokemično razlikovati, razvijajo se dendriti in aksoni, povečuje se število povezav (sinaps). Gostota povezav se področno razlikuje; v vidni skorji je največja v 4. mesecu po rojstvu, v prefrontalni skorji pa okoli 4. leta starosti (Huttenlocher in Dabholkar, 1997). Je pa gostota sinaps v celoti v možganih pri triletnikih za $50 \%$ večja kot pri odraslih. Meritve možganske presnovne aktivnosti - študije $\mathrm{z}$ uporabo pozitronske emisijske tomografije (PET) pri otrocih kažejo, da najvišje presnovne vrednosti, ki dosežejo plato, otroci dosežejo med tretjim in devetim letom starosti (Chugani, Phelps in Mazziotta, 1987). Nekateri iz tega sklepajo na povezavo med konektivnostjo in presnovno aktivnostjo, ki naj bi bili takrat najvišji.

Število povezav se spreminja glede na njihovo uporabo po načelu: uporabi ali izgubi. Sinapse, ki se uporabljajo istočasno, se med seboj povežejo in uskladijo. Ob rojstvu ima vsak nevron možganske skorje 2500 sinaps, do starosti
2-3 let se število poveča na 15000 . V prvem mesecu življenja število vseh sinaps poskoči s 50 trilijonov na 1 kvadrilijon. Če bi tako hitro raslo tudi dojenčkovo telo, bi se v tem času zredil s 4 na 80 kilogramov telesne teže.

Sinapse nastajajo, se krepijo ali izginjajo vse življenje, kar imenujemo plastičnost. Ti dinamični procesi na sinapsah nam omogočajo obdelavo informacij v otroštvu (razvojna plastičnost), učenje in pomnjenje še pozno $\mathrm{v}$ starost (plastičnost učenja in spomina) ter nadomestitev izgube funkcije ob npr. poškodbi (plastičnost, ki jo vzpodbudi poškodba). $\mathrm{V}$ grobem ločimo tri vplive na nastanek in izginotje sinaps: preko glutamata inducirane NMDA aktivnosti, ki se aktivira ob bolečini; kaspazni kaskadi, ki se aktivira ob okužbi ali vnetju, ter nevronsko aktivnost. Če torej vplivamo na aktivnost nevronov $\mathrm{s}$ spodbudnim okoljem, ki spodbuja učenje, se izogibamo bolečini, okužbi in vnetju, lahko sklepamo, da vplivamo na plastičnost in razvoj možganov.

V otroštvu se izrazijo genetske posebnosti ob vplivu okolja. Radi rečemo, da na razvoj v tem obdobju vpliva tako biološka narava kot okolje. V občutljivem obdobju, ki ga uravnavajo posebne molekule, vezane na biološko notranjo uro, izkušnje nepovratno vplivajo na razvoj določenih predelov živčevja. Pomembno vlogo igra 
vtisnjenje. $\mathrm{Za}$ različne predele možganov obstajajo različna občutljiva obdobja. Poznamo občutljivo obdobje za razvoj vida, razvoj gibalnih spretnosti, govor ipd. (Michel in Tyler, 2005).

$\mathrm{V}$ razvoju možganov so časovna obdobja, ki omogočajo $\mathrm{v}$ tistem času najbolj optimalen razvoj določenega področja možganov. Imenujemo jih občutljiva (tudi kritična) obdobja. Kar se naučimo v tistem času, se naučimo hitreje in bolj temeljito kot v kakšnem drugem obdobju. Žal to pomeni tudi, da zamujeno obdobje težje kasneje nadomestimo. Občutljivo obdobje omogoča kljub neustreznim izkušnjam $\mathrm{v}$ tej dobi še normalen razvoj živčevja. Kasneje, ko se občutljivo obdobje konča, so spremembe težje izvedljive. Nekatera področja možganov so pri v ranem otroštvu zlorabljanih ali hudo zanemarjanih otrocih lahko precej manjša kot enaka področja pri zdravih otrocih, ne glede na to, kaj se $\mathrm{z}$ otroki dogaja kasneje $\mathrm{v}$ mladosti. Romunske sirote oziroma kasneje posvojeni otroci iz romunskih sirotišnic niso v razvoju nikoli dosegli svojih vrstnikov kljub optimalnemu okolju, ki so mu bili kasneje izpostavljeni (Fisher, Ames, Chisholm in Savoie, 1997).

Za učenje je zelo pomemben vzgled. Časovno in vsebinsko bolj intenzivni pogovori z otrokom, branje in ljubeče okolje lahko povečajo otrokove govorne zmožnosti (Tucker-Drob in Harden, 2012). Prehrana in ljubeča skrb za otroke je za razvoj možganov izredno pomembna, kar so pokazali z raziskavami pri dojenih otrocih, otrocih, ki niso bili optimalno prehranjeni oziroma so utrpeli pomanjkanje hrane (Alaimo, Olson in Fongillo, 2001; Anderson, Johnstone in Remley, 1999).

$\mathrm{Na}$ starševstvo in vzgojo lahko gledamo kot na zunanje vplive na otrokov razvoj. Longitudinalne študije, ki so vključevale tudi dvojčke, so pokazale, da je ljubeče ukvarjanje staršev z otroki pri dveh letih vplivalo na bralne sposobnosti otrok dve leti kasneje. Zanimivo je, da so ugotavljali tudi obratno; otrokove sposobnosti so določale način in količino ukvarjanja. S primerjavo genetsko identičnih dvojčkov in sorojencev pa so ugotovili celo, da je bil vpliv genetike povsem enak vplivu vzgoje (TuckerDrob in Harden, 2012).

$\mathrm{Na}$ kakovost otrokovega življenja in tudi družine odločilno vpliva vzgoja. Intenzivni izbruhi besa, stiske, kričanja in jeze velikokrat niso znaki, da je otrok poreden, ampak kažejo na dejstvo, kako nezreli so še otroški možgani (Potegal in Davidson, 2003). Skorja čelnih režnjev še ni tako razvita, da bi lahko "sama od sebe« pomirila te čustvene izbruhe. Pri tem otrok potrebuje pomoč odraslega, velikokrat je to le bližina in pogovor, da se pomiri. Če so otrokove čustvene potrebe zadoščene, se $\mathrm{v}$ njegovih možganih začnejo razvijati odločilne povezave, kako ravnati v določenih čustvenih situacijah. Število in trajanje izbruhov trme in nasilnega vedenja, samopoškodbeno vedenje ter do predmetov nasilno vedenje pa so opozorilni znaki za vedenjske težave in so lahko odslikava razvojnih posebnosti možganov (Belden, Renick-Thomson in Luby, 2008).

V otroštvu se v možganih oblikujejo sistemi, ki so zelo pomembni za razvoj socialnih veščin in življenje $\mathrm{v}$ skupnosti. Prav pri razvoju socialnih veščin pridejo do izraza ne le naše genetske posebnosti pač pa tudi vplivi okolja. Zato se zlasti pri razvoju predelov možganov, ki sodelujejo pri socialnih veščinah, zdi ideja protoskorje najbolj verjetna. Predel fusiformne skorje, ki se pri odraslih selektivno aktivira ob prepoznavi obrazov, se oblikuje glede na signale, ki jih prejema iz fovee in preko ventralne vidne poti (Malach, Avidan, Lerner, Hasson in Levy, 2004). Predel fusiformne skorje je dodatno recipročno povezan s predelom parahipokampalnega režnja. Pri novorojenčkih ta predel skorje še ni specializiran, se pa oblikuje glede na dražljaje. Že novorojenček z izrednim zanimanjem opazuje obraze, kar pri njem aktivira subkortikalno pot, ki je identična odrasli subkortikalni poti prepoznavanja obrazov (Johnson, 2005). Zanimanje za obraze pri novorojenčkih je sicer res lahko pomenilo evolucijsko (verjetno tudi genetsko) prednost, ki jo predstavlja vzpostavitev stika $\mathrm{z}$ odraslim skrbnikom. Ne moremo pa mimo tega, da ponavljajoči dražljaj, kot je opazovanje človeškega obraza, pomembno vpliva na razvojno plastičnost kortikalne povezave in jo tako tudi oblikuje (Johnson, 2005; Johnson in Morton, 1991).

Hitrost procesiranja in kakovost izmenjave informacij je odvisna tudi od mielinizacije. Z leti se količina vode v možganskem tkivu zmanjšuje, veča pa se količina mielina. $\mathrm{V}$ obdobju 6 do 12 mesecev starosti pride do postopne, področno značilne menjave kakovosti mielina (Barkovich, Kjos, Jackson in Norman, 1988). Nekaj časa je veljalo splošno pravilo, da se do odrasle dobe povečuje količina mielina, torej bele možganovine, količina sive možganovine pa se zmanjšuje. Šele longitudinalne študije, ki jih izvaja skupina NIMH Pediatric Brain Imaging, so pokazale na določene razvojne posebnosti in rastne krivulje za posamezna področja sive možganovine, ki sledijo krivulji zvrnjene črke U (Giedd idr., 1999).

\section{Razvoj možganov v obdobju najstništva}

Obdobje najstništva je obdobje velikih nevrobioloških kot tudi vedenjskih sprememb, ki imajo svoj vzrok tudi v možganih. Zanimivo je, da so pri sesalcih spremembe, značilne za adolescenco, prisotne in jasno razpoznane pri različnih vrstah, kar si razlagamo $\mathrm{z}$ evolucijsko prednostjo tega, da se prepreči razmnoževanje znotraj genetsko zelo sorodnih posameznikov, ko ti postanejo spolno aktivni (Offer in Schonert-Reichl, 1992).

Pri najstnikih gre tako za strukturne spremembe kot tudi za spremembe v načinu delovanja. Anatomsko so možgani najstnika že praktično enako veliki kot pri odraslem. Skupna možganska prostornina pri 6 letih že dosega $95 \%$ svoje največje vrednosti, pri čemer se slikovni podatki pridobljeni $\mathrm{z}$ magnetno resonančnim slikanjem ujemajo s posmrtnimi poročili. Mali možgani dosežejo svojo polno velikost približno 2 leti kasneje (Giedd, 2008).

Največjo skupno prostornino dosežejo možgani pri fantih pri 14,5 letih, pri deklicah pa pri 11,5 letih (Giedd, 
2008). Ženske imajo na splošno za 9 \% manjše možgane kot moški in ta razlika ostane kljub popravkom na telesno višino in težo. Velikost možganov pa ne pove dovolj o samem delovanju, saj bi morali ob tem opisati tudi konektivnost in gostoto sinaps.

\section{Siva možganovina (skorja)}

Prostornina skorje sledi razvojni krivulji v obliki zvrnjene črke U, kjer je vrh, tj. največja prostornina , za različne režnje različna. Tako svojo največjo prostornino dosežejo čelni režnji pri deklicah v povprečju pri 11,0 letih, pri dečkih pa pri 12,1 letih, senčnični režnji pri deklicah pri 16,2 in pri dečkih pri 16,7 letih, temenski režnji pri deklicah pri 10,2 in pri dečkih pri 11,8 letih (Lenroot in Giedd, 2006). Nekateri kasnejši podatki vrh zamaknejo v zgodnejše obdobje: čelni režnji v povprečju pri deklicah pri 9,5 in pri dečkih pri 12,1 letih, senčnični režnji pri deklicah pri 10,0 in pri dečkih pri 11,0 letih, temenski režnji pri deklicah pri 7,5 in pri dečkih pri 9,0 letih (Giedd, 2008). Tik pred puberteto je torej prostornina skorje (sive možganovine) največja, nato pa se prostornina zmanjšuje. Rastne krivulje dosežejo svoj vrh prej v predelih primarnih funkcij, npr. motorično in senzorično področje, medtem ko predeli, ki integrirajo funkcije, dozorijo kasneje. Med zadnjimi doseže največjo prostornino dorzolateralna prefrontalna skorja, kjer se vrši nadzor impulzov, presoje, odločanja (Gogtay idr., 2004). Na spletni strani univerze UCLA so dostopni posnetki, kjer si zorenje lahko ogledate $» \mathrm{~V}$ živo«. (http://loni.ucla. edu/thompson/DEVEL/dynamic.html)

Spremembe v sivi možganovini lahko v post-mortem študijah razložimo s propadom in obrezovanjem sinaps. Podobne spremembe v smislu izgube moči, vidne na kvantificiranem posnetku EEG ter tudi na študijah presnove, sledijo podobni zvrnjeni U-krivulji kot jo ima prostornina, vidna na posnetkih z MRI (Giedd, 2008).

Globoke strukture, kot so bazalni gangliji, obe amigdali in hipokampusa, postanejo večje, spremeni pa se tudi njihovo delovanje. Kavdatno jedro doseže svoj prostorninski vrh pri deklicah pri 7,5 letih in pri 10 letih pri dečkih (Giedd, 2008). Zanimivo je, da obstajajo podatki, ko se prostornina hipokampusa znatno poveča le pri dekletih, kar si razlagajo $\mathrm{z}$ večjo gostoto estrogenskih receptorjev. Amigdala pa naj bi se bolj povečala pri fantih, kar si razlagajo z večjo gostoto androgenskih receptorjev pri primatih. Konektivnost in procesiranje informacij se pri obeh spolih v obdobju najstništva poveča, spremeni se razmerje med delovanjem limbičnih in subkortikalnih struktur $\mathrm{v}$ korist delovanja čelnih režnjev (Luna in Sweeney, 2004; Shaw idr., 2008).

\section{Bela možganovina in mielinizacija}

Količina mielina tekom razvoja skoraj konstantno narašča in to v vseh režnjih približno enako. Količina bele možganovine naj bi se začela zmanjševati šele po 30. do 40. letu (Bartzokis, Beckson, Nuechterlein, Edwards in
Mintz, 2001). Recipročna odvisnost nevronov in glije se kaže $s$ proliferacijo in preživetjem oligodendrocitov in odlaganjem mielina ob vplivu proženja nevronov pa tudi obratno: oligodendrociti preko rastnih faktorjev vplivajo na rast aksonov in delovanje ionskih kanalčkov nevronov (Fields in Stevens-Graham, 2002).

Proksimalne poti zorijo pred distalnimi, senzorične poti pred motoričnimi, projekcijska vlakna pred asociacijskimi (Volpe, 2008). Tista vlakna, ki dozorijo kasneje, so tanjša in vsak oligodendrocit ovije več aksonov kot sicer.

Korpus kalozum vsebuje skoraj 200 milijonov mieliniziranih vlaken, katerih mielinizacija napreduje konstantno tekom adolescence. Vpliva spola na zorenje in obliko korpus kalozuma pa glede na nasprotujoče podatke ne moremo oceniti (Lenroot in Giedd, 2006).

\section{Delovanje možganov $\mathbf{v}$ adolescenci}

Najstništvo je priložnost, da dozorimo v odraslega. Zato ob dobri biološki osnovi potrebujemo tudi zglede, zaupanje in vzpodbudno okolje. To je za najstnika izrazito težko, uči se še o sebi, drugih, svetu, tudi njegovi možgani delujejo drugače. Na McLean Hospital v Belmontu so s poskusi s fMRI ugotovili, da najstniki izraza na obrazu niso prepoznali enako kot odrasli. Kar so odrasli prepoznali kot strah, so najstniki prepoznali kot zmedenost, šok ali jezo. $\mathrm{Ob}$ tem so uporabili bolj senčnične režnje in amigdalo, odrasli pa prefrontalno skorjo (Yurgelun-Todd in Killgore, 2006).

Najstniki so zaradi svoje impulzivnosti, spontanosti in odkritosti, ki so vezane na prefrontalno skorjo, in svoje neustrašnosti, vezane na amigdalo, in svojo željo po novem, neodkritem, lahko pravi navdih odraslim. So pogumni, neustrašni, sprejmejo tveganje, se družijo s sebi enakimi, kršijo pravila družbe in ne upoštevajo avtoritete, so telesno izredno zmogljivi in ne spijo veliko. Na vedenje najstnika pa kljub vsemu zelo vplivajo starši. Konec 2009 so v študiji, objavljeni v Journal of Research on Adolescence, ugotovili, da se starši, ki so imeli negativna pričakovanja do svojih otrok, kasneje spopadejo z bolj škodljivimi vedenji najstnikov (Buchanan in Hughes, 2009). Najstniki, ki so bili s starši bolj povezani, pa so bili bolj akademsko uspešni in zadovoljni.

Med najstništvom, ki je sicer obdobje biološke in fizične moči, se izrazijo nekatere bolezni, ki so bile pred tem prikrite. Tako se v najstništvu lahko prvič izrazi depresija, shizofrenija. Motnje avtističnega spektra ADHD in zlasti Tourettov sindrom pa nasprotno lahko navidezno izzvenijo oziroma se njihova pojavnost omili, saj se okrepijo določeni mehanizmi, zlasti zrelost kortikalnih struktur, ki omogočijo inhibicijo subkortikalnih struktur. V najstništvu se namreč izrazito poveča aktivacija predelov kognitivnega nadzora; prefrontalna in sprednja cingulatna skorja ter temenski del skorje (Luna in Sweeney, 2004; Moriguchia in Hirakic, 2011). Pomembnejše značilnosti delovanja možganov tekom razvoja in v obdobju zrelosti so povzete v tabeli 1 . 
Tabela 1. Delovanje možganov tekom razvoja in v obdobju zrelosti

\begin{tabular}{ll}
\hline Možgani v razvoju & Zreli možgani \\
\hline Razvojna plastičnost & Plastičnost, ki jo vzpodbudi poškodba \\
Plastičnost, ki jo vzpodbudi poškodba & Plastičnost spomina in učenja \\
Plastičnost spomina in učenja & Obstoj nevromodulatornih sistemov \\
Kritična in občutljiva obdobja & \\
Večja občutljivost / ranljivost & \\
Višja hitrost procesiranja & \\
Razvoj nevromodulatornih sistemov & \\
\hline
\end{tabular}

\section{Razdelitev možganov s filogenetskega vidika}

V razvoju posameznika pogosto opazimo podobnosti s filogenetskim razvojem. Pri otrocih, ki še nimajo zrelih določenih možganskih struktur, dobro delujejo praviloma evolucijsko mlajše strukture. $Z$ evolucijskega vidika lahko zelo poenostavljeno možgane razdelimo v 3 dele (MacLean, 1990). Najstarejši so »plazilski« možgani, ki so ostali skozi evolucijo precej enaki in jih ljudje delimo z vsemi živalmi s hrbtenico. Podaljšana hrbtenjača je del možganov, ki se je razvil v zgodnjem evolucijskem obdobju in je pri plazilcih prevladujoči del možganov. Funkcija podaljšane hrbtenjače je delovanje srčnožilnega sistema in dihanja ter zagotavljanje preživetja po načelu »boj ali beg«. Ko prevladuje aktivnost tega dela možganov, so zmanjšane zmožnosti uporabe ostalih predelov, zlasti predelov, ki so odgovorni za čustvene odzive in mišljenje. $\mathrm{V}$ podaljšani hrbtenjači so centri, ki nadzorujejo telesne funkcije kot so dihanje, telesna temperatura in nagoni. Donošeni novorojenčki imajo praviloma zrele strukture za nadzor bitja srca, dihanje, hranjenje, medtem ko imajo nedonošeni oziroma nezreli otroci lahko težave $\mathrm{z}$ dihalnimi premori, lahko pride celo do življenjsko ogrožajočega dogodka z zastojem dihanja. Evolucijsko mlajši so »sesalski« možgani. To je predel možganov, kamor prištevamo limbični sistem, tj. polkrožen predel, ki se nahaja $\mathrm{v}$ osrednjem delu možganov. K njemu prištevamo tudi amigdaloidno jedro in hipokampus. Limbični sistem skrbi za motivacijo in čustva in je značilen za vse sesalce. Nadzoruje gibanje, telesno temperaturo, delovanje notranjih organov in posreduje informacije čutil do možganske skorje. Omogoča bolj specifične odzive na okolje in kontrolo telesa ter preko talamusa in avtonomnega živčevja uravnava prebavo, tekočinsko ravnovesje, temperaturo in tlak; preko hipokampusa omogoča spomin ter preko amigdaloidnega jedra prepoznavo in pripisovanje čustvene konotacije dogodkom. Povezave med hipokampusom in amigdaloidnim jedrom omogočajo nadzor nad instinkti, občutki jeze, strahu in pripadnosti pa se povezujejo $\mathrm{z}$ vedenjem kot je skrb, boj ali beg. Delovanje teh struktur uravnava dotok informacij iz evolucijsko najmlajšega predela - skorje, ki pri otrocih še ni zrela in zori še pozno v adolescenco. Pri otrocih lahko zaradi nezrelosti delovanja zlasti izvršilnih funkcij opazujemo neposrednost, impulzivnost ter nezmožnost predvidevanja dogodkov. Evolucijsko najmlajši del možganov je možganska skorja ali neokorteks. Omogoča usklajeno delovanje možganov in kompleksne procese, kot so mišljenje, sklepanje, govor, odločanje in namerno vedenje.

Zorenje možganskih struktur poteka praviloma v smeri od zadaj-naprej in od spodaj-navzgor. Zorenje gibalnih sposobnosti in struktur pa poteka praviloma od zgorajnavzdol in od sredine proti periferiji (Einspieler, Prechtl, Bos, Ferrari in Cioni, 2004). Zato pri otroku vidimo, kako najprej nadzoruje držo glave, nato trupa, šele na koncu otrok usvoji hotene gibe nog in rok. Vidimo tudi, da so ob rojstvu zreli najbolj spodnji predeli, kjer ležijo centri za osnovne življenjske funkcije, med prvimi dozori tudi predel vidne skorje, zadnji pa je čelni reženj z izvršilnimi funkcijami.

S pomočjo sodobnih slikovnih metod kot je slikanje $\mathrm{z}$ difuzijskimi tenzorji (angl. diffusion tensor imaging - DTI) si lahko poleg grobih morfoloških značilnosti tkiva prikažemo tudi klinično pomembne podrobnosti kot je prikaz, določitev in količinsko opredelitev poteka snopov bele možganovine, pri čemer lahko tudi izberemo točno določen snop, npr. kortikospinalno progo roke (Bregant, Derganc in Neubauer, 2012). Metoda postaja pomembno orodje tako za nevroznanstveno kot tudi klinično uporabo.

Na sliki 3 vidimo potek vlaken pri zdravem, 20-letnem mladeniču, kot ga vidimo na slikanju z MR z dodatnim slikanjem $\mathrm{z}$ difuzijskimi tenzorji.

Vedno se moramo zavedati, da je delovanje možganov kompleksno in ne moremo preprosto enačiti delovanja možganskih struktur z našim vedenjem. Praktično nikoli tudi ni vedenje omejeno na zgolj eno samo anatomsko področje. Gre namreč za neke vrste selekcijski sistem, ki s prepoznavo vzorca vzpostavlja nove sisteme, ki so lahko vedno različni. Prav ta široka paleta omogoča izbor vzorcev mišljenja in delovanja, ki so bili skozi evolucijo koristni. Sistemi so se tako oblikovali v danes prepoznane anatomske strukture oziroma celo obsežne anatomske sisteme. 


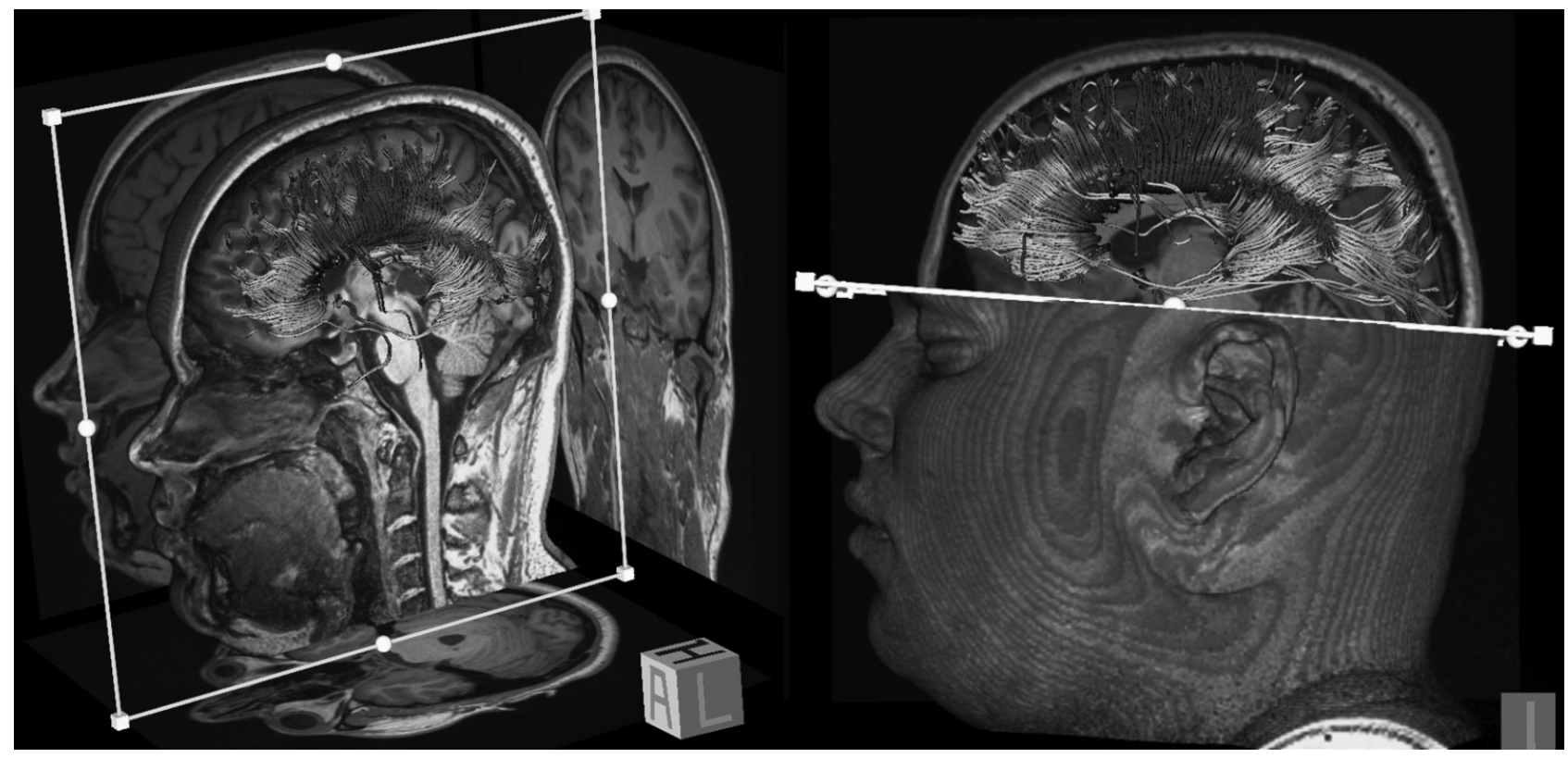

Slika 3. Prikaz poteka vlaken pri 20 letnem mladeniču kot ga vidimo na slikanju z MRI (DTI).

\section{Zaključek}

Longitudinalne študije so omogočile vpogled v rast, razvoj in zorenje možganov (Giedd idr., 1999; Kraemer, Yesavage, Taylor, in Kupfer, 2000). Če je bil naš razvoj optimalen, smo ob koncu 20 let sposobni in zdravi odrasli z zrelimi možganskimi strukturami, ki nam omogočajo, da v vsakdanje življenje ne vlagamo večjih naporov. Kljub zaključenemu razvoju so naši možgani še vedno sposobni novega učenja, zaradi plastičnosti se vzpostavljajo nove povezave, lahko nastanejo celo novi nevroni. Vendar je to vezano na dolgotrajnejše procese kot v mladosti. Bolj kot v mladosti je pomembna vloga sprednjih delov možganov, ki so šele sedaj popolnoma dozoreli in lahko uravnavajo motivacijo in izvajajo izvršilne funkcije. Zdrav srčnožilni sistem, ki je vezan na življenjski slog, pomembno vpliva na optimalno delovanje možganov.

Zgodnje otroštvo narekuje razvoj in zorenje možganov. Genetska zasnova in primerno okolje oblikujejo biološke sisteme, ki se kasneje lahko aktivirajo in so ključnega pomena $\mathrm{v}$ življenju. V otroštvu so kritična obdobja, torej izjemna dovzetnost za specifično učenje ter večja sposobnost preoblikovanja in kompenziranja možganov kot kasneje v odraslosti. Žal slednje pomeni tudi izjemno dovzetnost za negativno stimulacijo kot je čustvena zloraba, ponavljajoča bolečina, zloraba drog, nikotina, alkohola, ki ima zato $\mathrm{v}$ določenem obdobju znatne in dolgotrajne posledice. Prehrana, dostopnost medicinske oskrbe, varnost in predvidljivost fizičnega okolja, družinsko okolje, kvaliteta in dnevna skrb za otroka $\mathrm{v}$ otroštvu pomembno vplivajo na razvoj možganov.

Šele sodobne metode kot so slikanje $\mathrm{z}$ magnetno resonanco so nam omogočile vpogled $\mathrm{v}$ razvoj, rast in zorenje struktur v možganih pri zdravih otrocih. Nekatere izsledke nevroanatomije smo uspeli povezati in osvetliti s psihološkimi spoznanji. Z razumevanjem razvoja zdravih otrok tudi lažje razumemo delovanje možganov, ki so bili oškodovani med razvojem.

\section{Literatura}

Ackerman, S. (1992). Discovering the brain. Washington, DC: National Academy Press.

Alaimo, K., Olson, C. M. in Frongillo, E. A. (2001). Food insufficiency and American school-aged children's cognitive, academic, and psychosocial development. Pediatrics, 108(1), 44-53.

Anderson, J. W., Johnstone, B. M. in Remley, D. T. (1999). Breast-feeding and cognitive development: A metaanalysis. American Journal of Clinical Nutrition, 70(4), 525-535.

Barkovich, A. J., Kjos, B. O., Jackson, D. E. in Norman, D. (1988). Normal maturation of the neonatal and infant brain: MR imaging at 1.5 T. Radiology, 166, 173-180.

Bartzokis, G., Beckson, M., Nuechterlein, K. H., Edwards, N. in Mintz, J. (2001). Age-related changes in frontal and temporal lobe volumes in men: A magnetic resonance imaging study. Archives of General Psychiatry, 58(5), 461-465.

Belden, A. C., Renick-Thomson, N. R. in Luby, J. L. (2008). Temper tantrums in healthy versus depressed and disruptive preschoolers: Defining tantrum behaviors associated with clinical problems. Journal of Pediatrics, 152(1), 117-122.

Bregant, T. (2010). Razvoj možganov [Brain development]. Proteus, 73(4), 168-174.

Bregant, T., Derganc, M. in Neubauer, D. (2012). Uporaba magnetnoresonančnega slikanja $\mathrm{Z}$ difuzijskimi tenzorji $\mathrm{v}$ pediatriji. [Diffusion-tensor magnetic 
resonance imaging in pediatrics]. Zdravniški Vestnik, 81(7-8), 533-542.

Buchanan, C. M. in Hughes, J. L. (2009). Construction of social reality during early adolescence: Can expecting storm and stress increase real or perceived storm and stress? Journal of Research on Adolescence, 19(2), 261-285.

Cedric, P., Koolschijn, M. P., Schel, M. A., de Rooij, M. A., Rombouts, S. in Crone, E. A. (2011). Three-year longitudinal functional magnetic resonance imaging study of performance monitoring and test-retest reliability from childhood to early adulthood. The Journal of Neuroscience, 31(11), 4204-4212.

Chugani, H. T., Phelps, M. E. in Mazziotta, J. C. (1987). Positron emission tomography study of human brain function development. Annals of Neurology, 22, 487-497.

Clowry, G., Molnar Z. in Rakic, P. (2010). Renewed focus on the developing human neocortex. Journal of Anatomy, 217, 276-288.

Einspieler, C., Prechtl, H. F. R., Bos, A. F., Ferrari, F. in Cioni, G. (2004). Prechtl's Method on the qualitative assessment of general movements in preterm, term and young infants. Clinics in Developmental Medicine, 197. London: Mac Keith Press; Cambridge, UK: Cambridge University Press.

Fields, R. D. in Stevens-Graham, B. (2002). New insights into neuron-glia communication. Science Neuroscience, 298(5593), 556-562.

Finlay, B. L. in Darlington, R. B. (1995). Linked regularities in the development and evolution of mammalian brains. Science, 268, 1578-1584.

Fisher, L., Ames, W. E., Chisholm, K. in Savoie, L. (1997). Problems reported by parents of Romanian orphans adopted to British Columbia. International Journal of Behavioral Development, 20(1), 67-82.

Giedd, J. N. (2008). The teen brain: Insights from neuroimaging. Journal of Adolescent Health, 42, 335-343.

Giedd, J. N., Blumenthal, J., Jeffries, N. O., Castellanos, F. X., Liu, H., Zijdenbos, A., Paus, T., Evans, A. C. in Rapoport, J. L. (1999). Brain development during childhood and adolescence. A longitudinal MRI study. Nature Neuroscience, 2(10), 861-863.

Gogtay, N., Giedd, J. N., Lusk, L., Hayashi, K. M., Greenstein, D., Vaituzis, A. C., Nugent, T. F., Herman, D. H., Clasen, L. S, Toga, A. W., Rapaport, J. L. in Thompson, P. M. (2004). Dynamic mapping of human cortical development during childhood through early adulthood. PNAS, 101(21), 8174-8179.

Haslam, R. H. A. (2000). Neural tube defects. V R. E. Behrman (ur.), Nelson textbook of pediatrics, (str. 10-37). Philadelphia: Saunders.

Huppi, P. S. in Inder, T.E. (2001). Magnetic resonance techniques in the evaluation of the perinatal brain: Recent advances and future directions. Seminars in Neonatology, 6(2), 195-210.

Huttenlocher, P. R. in Dabholkar, A. S. (1997). Regional differences in synaptogenesis in human cerebral cortex. Journal of Comparative Neurology, 387, $167-178$.

Johnson, M. H. (2005). Sub-cortical face processing. Nature Review Neuroscience, 6, 766-774.

Johnson, M. H. in Morton, J. (1991). Biology and cognitive development: The case of face recognition. Oxford: Blackwell.

Kennedy, H. in Dehay, C. (1993). Cortical specification of mice and men. Cerebral Cortex, 3(3), 171-186.

Kostovic, I. in Rakic, P. (1990). Developmental history of the transient subplate zone in the visual and somatosensory cortex of the macaque monkey and human brain. The Journal of Comparative Neurology, 297(3), 441-470.

Kraemer, H. C., Yesavage, J. A., Taylor, J. L. in Kupfer, D. (2000). How can we learn about developmental processes from cross-sectional studies, or can we? American Journal of Psychiatry, 157, 163-171.

Lenroot, R. K. in Giedd, J. N. (2006). Brain development in children and adolescents: Insights from anatomical magnetic resonance imaging. Neuroscience and Biobehavioral Reviews, 30, 718-729.

Levine, D. in Barnes, P. D. (1999). Cortical maturation in normal and abnormal fetuses as assessed with prenatal MR imaging. Radiology, 210, 751-758.

Luna, B. in Sweeney, J. A. (2004). The emergence of collaborative brain function: fMRI studies of the development of response inhibition. Annals of $N Y$ Academic Science, 1021, 296-309.

MacLean, P. D. (1990). The triune brain in evolution: Role in paleocerebral functions. New York: Plenum Press.

Malach, R., Avidan, G., Lerner, V., Hasson, U. in Levy I. (2004). The cartography of human visual object areas. V Kanwisher, N. in Duncan, J. (ur.), Attention and performance $X X$ : Functional neuroimaging of visual cognition (str. 195-204). Oxford: Oxford University Press.

Michel, G.F. in Tyler, A. N. (2005). Crical period: A history from transitons of questions from when, to what, to how. Developmental Psychobiology, 46(3), 156-162.

Miyashita-Lin, E. M., Hevner, R., Montzka Wassarman, K., Martinez, S. in Rubenstein, J. L. R. (1999). Early neocortical regionalization in the absence of thalamic innervation. Science, 285, 906-909.

Miller, S. P. in Ferriero, D. M. (2009). From selective vulnerability to connectivity: Insights from newborn brain imaging. Trends in Neuroscience, 32(9), 496-505.

Moriguchia, Y. in Hirakic, K. (2011). Longitudinal development of prefrontal function during early childhood. Developmental Cognitive Neuroscience, 1(2), 153-162.

Offer, D. in Schonert-Reichl, K. A. (1992). Debunking the myths of adolescence: Findings from recent research. Journal of the American Academy of Child and Adolescent Psychiatry, 31(6), 1003-1014.

Potegal, M. in Davidson, R. J. (2003). Temper tantrums in young children: Behavioral composition. 
Developmental and Behavioral Pediatrics, 24, 140-147.

Rakic, P. (1988). Specification of cerebral cortiacal areas. Science, 241(4862), 170-176.

Rakic, P. (1995). A small step for the cell, a giant leap for mankind: A hypothesis of neocortical expansion during evolution. Trends in Neuroscience, 383-388.

Schmitt, J. E., Wallace, G. L. in Rosenthal, M. A. (2007). A multivariate analysis of neuroanatomic relationships: A genetically informative pediatric sample. Neuroimage, 35, 70-82.

Shatz, C. J. (2002). Emergence of order in in visual system development. V Johnson, M. H. (ur.), Brain development and cognition, (str. 231-244). Oxford: Blackwell.

Shaw, P., Kabani, N. J., Lerch, J. P., Eckstrand,K., Lenroot, R., Gogtay., N., Greenstein, D., Clasen, L., Evans, A., Rapoport, J. L., Giedd, J. N. in Wise S. P. (2008). Neurodevelopmental trajectories of the human cerebral cortex. Journal of Neuroscience, 28, 3586-3594.

Tucker-Drob, E. M. in Harden, K. P. (2012). Early childhood cognitive development and parental cognitive stimulation: Evidence for reciprocal geneenvironment transactions. Developmental Science, $15,250-259$.

Volpe, J. J. (2008). Neurology of the newborn. Philadelphia: Saunders Elsevier.

Yakovlev , P. I. in Lecours, A. (1967). The myelogenetic cycles of regional maturation of the brain. $\mathrm{V}$ Minkovski, A. (ur.), Regional development of the brain in early life (str. 3-65). Oxford: Blackwell.

Yurgelun-Todd, D. A. in Killgore, W. D. S. (2006). Fearrelated activity in the prefrontal cortex increases with age during adolescence: A preliminary fMRI study. Neuroscience, 406(3), 194-199. 